\title{
Measurements and evaluation of some electrolytes concentrations in spleens of imported sheep to Sulaimani province
}

\author{
E.A. Saeed and K.A. Muhammad \\ Department of Animal Science, College of Agricultural Science, University of Sulaimani, Iraq \\ email: elham.husain@univsul.edu.iq
}

(Received March 7, 2018; Accepted October 1, 2018)

\begin{abstract}
The aim of this study was to determine the correlation between some biometrical measurements (length and width) and some electrolytic concentration $\left(\mathrm{Na}^{+}, \mathrm{K}^{+}\right.$and $\left.\mathrm{Cl}^{-}\right)$in sheep spleen. This study was conducted on 19 spleens of male sheep, they were imported from Syria to Sulaimani province, aged between less than 1 year to 1.5 year. The results showed that the mean values of weight were $108 \mathrm{gm}$ and mean values of length and width of the spleens were $13.72 \mathrm{~cm}$ and $9.05 \mathrm{~cm}$, respectively. Also, the mean values of $\mathrm{Cl}^{-}, \mathrm{Na}^{+}$and $\mathrm{K}^{+}$concentration were $14.17 \mathrm{mmol} / \mathrm{L}, 6.58 \mathrm{mmol} / \mathrm{L}, 32.89 \mathrm{mmol} / \mathrm{L}$, respectively. The correlation coefficient between weight and width was $(r=0.661, P=0.002)$ was a higher correlation with $\mathrm{R}^{2}=0.437$. Also It was $(r=0.932, \mathrm{P} \leq 0.0001)$ between $\mathrm{Na}^{+}$and $\mathrm{K}^{+}$which was a high correlation, with the higher value of $\mathrm{R}^{2}=0.869$. The results showed the negative correlation between weight and $\mathrm{Na}^{+}$, weight and $\mathrm{K}^{+}$with $(\mathrm{r}=-0.161, \mathrm{P}=0.509)$ and $(\mathrm{r}=-0.214, \mathrm{P}=0.379)$, respectively. However, it showed the positive correlation between other parameters; weight, length, width , $\mathrm{Na}^{+}, \mathrm{K}^{+}$and $\mathrm{Cl}^{-}$, the correlation coefficient $(\mathrm{r}=0.421, \mathrm{P}=0.072)$ between width and $\mathrm{Cl}^{-}$was the highest correlation, and the value $\mathrm{R}^{2}=0.177$. In conclusion, our study shows the positive correlation between some parameters (weight, length and width) and some electrolytes concentration $\left(\mathrm{Na}^{+}, \mathrm{K}^{+}\right.$and $\left.\mathrm{Cl}^{-}\right)$and the highest correlation between width and $\mathrm{Cl}^{-}$, however there was a negative correlation between weight and $\mathrm{Na}^{+}$and between weight and $\mathrm{K}^{+}$in sheep spleen.
\end{abstract}

Keywords: Spleen, Biometrical parameter, Electrolytes, Sheep

Available online at http://www.vetmedmosul.com

\section{مقايس وتقيم بعض تركيزات الإكترونيات في الطحال الأغنام المستوردة الى محافظة السليمانية الهام احمد حسين سعيد و كارزان عبدالقادر احمد محم}

الهدف من هذه الدر اسة هو تحديد العلاقة بين بعض القياسات البيومنرية ( الطول و العرض) وبعض التركيز الالكتروليتي (C Na

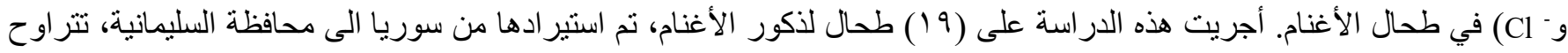

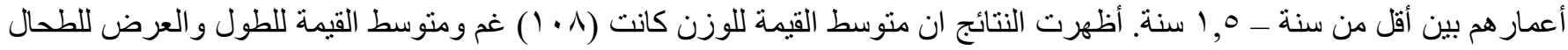

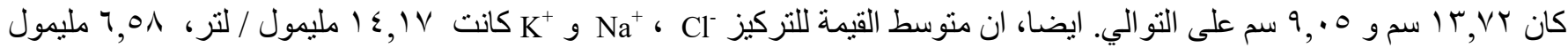

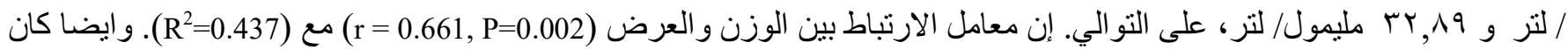

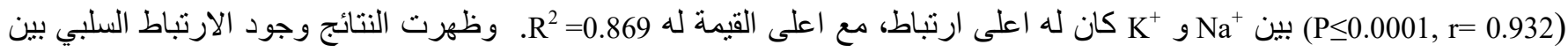
الوزن و +

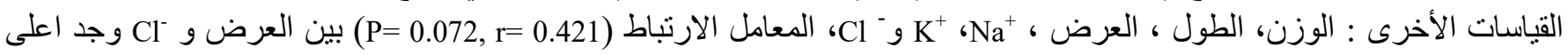

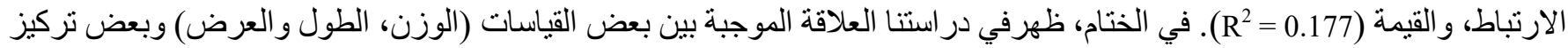

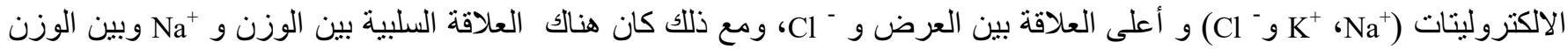

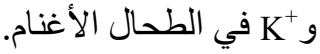




\section{Introduction}

Spleen is defined by (1) as the largest and major secondary lymphatic organ, and which works as a filter for blood, also reserves iron which can be used in haemoglobin synthesis. Holocomb (2) has described sheep as an important source of meat, milk and wool production. Also, Spleen defined as mass tended to be larger in sheep with lower residual feed intake regardless of diet type (3). Many diseases cause a change in fluids and electrolyte balance $(4,5)$. Electrolytes play an important role in all parts of animal life. Electrolytes are distributed in body fluids (6).The most important sodium's functions is maintaining osmotic balance cellular uptake of glucose and amino acid transport (7). Salt Institute (8), defined salt consist of 2 elements $(\mathrm{NaCl})$ as an essential in many plants and in the diet of human and animals. Mongin (9) and Leeson and Summers (10) determined the function of sodium as the principal cation of extracellular fluid, which is involved in numerous functions including the regulation of extracellular fluid volume, acid base balance, cell membrane potential, nerve function, and the absorption of glucose and amino acids. Dietary Electrolyte Balance $(\mathrm{DEB}=\mathrm{Na}+\mathrm{K}-\mathrm{Cl}$, $\mathrm{mEq} / \mathrm{kg}$ diet), according to Mongin (9), refers to the difference between positive and negative ions present in the diet $\left(\mathrm{Na}^{+}+\mathrm{K}^{+}-\mathrm{Cl}^{-}\right)$and it is commonly expressed as $\mathrm{mEq} / \mathrm{kg}$ of dry matter $(\mathrm{DM})$. the established value that express the quantity and relation among them is called Mongin Number (MN) (11). $\mathrm{MN}=\mathrm{mEq} \mathrm{Na}^{+}+\mathrm{mEqK}^{+}$$\mathrm{mEqCl}-$.Potassium is essential for various physiologic processes such as cell volume regulation, electrolyte balance, membrane potential, and muscle contraction (12). Extracellular $\mathrm{K}+$ concentration $([\mathrm{K}+])$ is tightly regulated in mammals, and this is critical for normal membrane potential and cell functions $(13,14)$. Potassium also interacts with both sodium and chloride to control fluid and electrolyte balances and assists in the conduction of nereve impulse (15). Mounib and Evans (16) compared kidney $\mathrm{Na}$ and $\mathrm{K}$ levels in lambs (1 year old), adults (4 years old) and aged sheep (6-8 years). But, there are limited information about the electrolytic concentration $\left(\mathrm{Na}^{+}, \mathrm{K}^{+}\right.$and $\left.\mathrm{Cl}^{-}\right)$in sheep spleen Determination of the spleen size has been done using various parameters of the spleen such as the width (17-19), the volume $(20,21)$ and the ratio (22). Because routine method for determination (electrolytes) is measuring in the serum only, was hypothesized that spleen tissue is the most appropriate sample material for the measurement the value of $\left(\mathrm{Na}^{+}, \mathrm{K}^{+}\right.$and $\left.\mathrm{Cl}^{-}\right)$, there for this study aimed to evaluate the value of (electrolytes) in spleen tissue.

The aim of present study is to determine the correlation between some biometrical measurements (length, width) and some electrolytic concentration $\left(\mathrm{Na}^{+}, \mathrm{K}^{+}\right.$and $\left.\mathrm{Cl}^{-}\right)$in sheep spleens.

\section{Material and Methods}

A total of 19 spleens from apparently healthy slaughtered animals were aged (under 1 year to 1.5 year) collected and transported to the lab of Animal Science department in the College of Agriculture Science of Sulaimania University, for gross some biometrical measurements and some biochemical test.

Biometric parameters of the spleen, were recorded on spleen sample including: Spleen weight (gm) was measured using digital balance, spleen length was measurement between two opposite highest vertical points of the spleen using a meter scale $(\mathrm{cm})$ and spleen width between two opposite mid-point of the spleen, measured using a meter scale $(\mathrm{cm})$. after biometric measurement of each spleen sample, about ( $2 \mathrm{gm})$ of each spleen sample were taken and manually homogenized in $(5 \mathrm{ml})$ distilled water and immigrated for about $(8 \mathrm{~min})$, then centrifuge have been done by use (small bench centrifuge) for (at least 15 minutes at 1600 RPM), after centrifugation, the supernatants were separated and kept at $\left(3-4 \mathrm{C}^{\circ}\right)$ in refrigerator until transported to the laboratory for biochemical analysis. Then, the supernatants were used to determine some electrolytes concentration (mmol/L) (sodium $\left(\mathrm{Na}^{+}\right)$, potassium $\left(\mathrm{K}^{+}\right)$and chloride $\left(\mathrm{Cl}^{-}\right)$. All tests were done by (Cobas C311 (Germany) - fully automatic calorimetric method FDA approved Kits) method. Data collected were subjected to statistical analysis using (XLSTAT 2016. 02). Correlation between some biometric parameters (weight $(\mathrm{gm})$, length $(\mathrm{cm})$ and width $(\mathrm{cm})$ ) and some electrolytes concentration $\left(\mathrm{Na}^{+}, \mathrm{K}^{+}\right.$and $\left.\mathrm{Cl}^{-} \mathrm{mmol} / \mathrm{L}\right)$ was done using Pearson's correlation test.

\section{Results and Discussions}

Niederau el al. (23), found that information about the diagnosis and course of the gastrointestinal and hematologic diseases can be obtained achieved from the splenic size. Electrolytes are distributed in body fluids and play a vital role in all stages of animal life (6). The biometrical measurements of the spleens of sheep are presented in figure 1.

Figure 1 show that mean value weight of spleen sheep was $108 \mathrm{gm}$, also the mean value of length and width in spleen sheep were (13.72 and 9.05) $\mathrm{cm}$, respectively. The values obtained in this study in sheep spleen were differ to those previously reported in Awasi sheep by Khalel (24) measured spleen weight about $69 \pm 6.663$ gm in Awasi sheep. Khalel (24) also measured average length and width of spleen of Awasi sheep to be $9.93 \pm 0.342 \mathrm{~cm}$ and $6.48 \pm$ $0.233 \mathrm{~cm}$, respectively. 


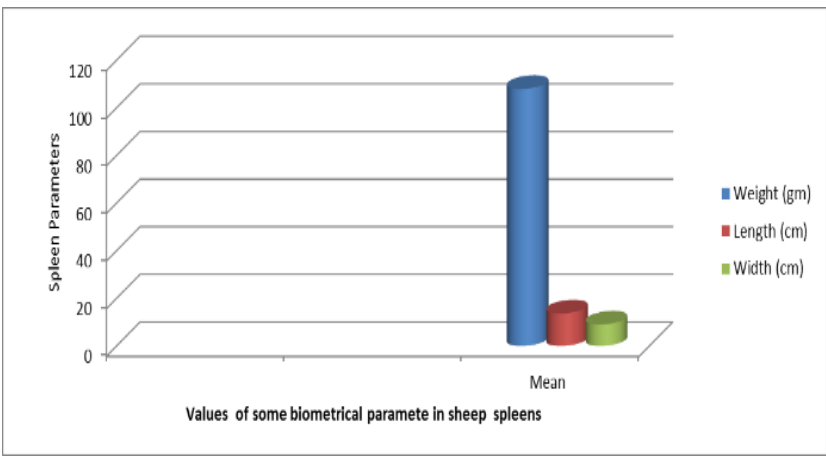

Figure 1: Values of some biometrical parameters in sheep spleens.

Figure (2) shows that means value of sodium concentration $\left(\mathrm{Na}^{+}\right)$as well as Potassium $\left(\mathrm{K}^{+}\right)$and Chloride $\left(\mathrm{Cl}^{-}\right)$in sheep spleen. mean values of $\mathrm{Na}^{+}, \mathrm{K}^{+}$and $\mathrm{Cl}^{-}$were $(6.58,32.89$ and 14.17$) \mathrm{mmol} / \mathrm{L}$, respectively. (Piccione et al. (25) studied the seasonal concentrations of $\mathrm{Na}, \mathrm{K}$, and $\mathrm{Cl}$ ions all over a year and he found somehow variation in those levels. Electrolytes are a critical element in cellular metabolism, muscle contraction, nerve transmission, and enzyme reactions (26). The increased intracellular calcium is involved in the contraction of vascular smooth muscle cells and is thus involved in the development of elevated blood pressure (27).

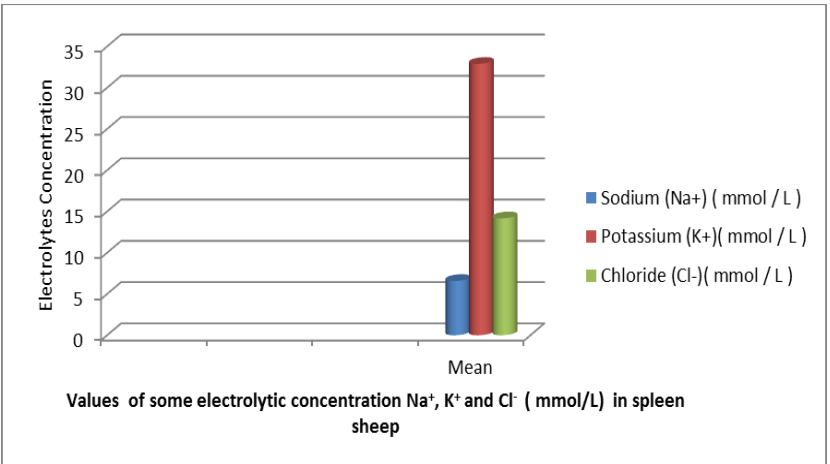

Figure 2: Values of some electrolytic concentration $\mathrm{Na}^{+}, \mathrm{K}^{+}$ and $\mathrm{Cl}^{-}(\mathrm{mmol} / \mathrm{L})$ in sheep spleens.

In table 1 show the (correlation, $\mathrm{P}$ - value and $\mathrm{R}^{2)}$ between some biometrical parameters weight (gm), length $(\mathrm{cm})$ and width $(\mathrm{cm})$ in sheep spleen. Results show the positive correlation between weight and length $(r=0.604$, $\mathrm{P}=0.006)$, between length and width $(\mathrm{r}=0.654, \mathrm{p}=0.002)$ and the correlation coefficient between weight and width $(r=0.661, p=0.002)$ is a high correlation. Coefficient of determination $\left(R^{2}\right)$ between weight and length $\left(R^{2}=0.364\right)$, between weight and width $\left(R^{2}=0.437\right)$ and between length and width $\left(R^{2}=0.427\right)$.
Table 1: The correlation between biometrical parameters; weight, length and width of sheep spleen

\begin{tabular}{ccc}
\hline Spleen parameters & Length $(\mathrm{cm})$ & Width $(\mathrm{cm})$ \\
\hline & $r=0.604$ & $r=0.661$ \\
Weight $(\mathrm{gm})$ & $\mathrm{P}=0.006$ & $\mathrm{P}=0.002$ \\
& $\mathrm{R}^{2}=0.364$ & $\mathrm{R}^{2}=0.437$ \\
Length $(\mathrm{cm})$ & & $r=0.654$ \\
& & $\mathrm{P}=0.002$ \\
& & $\mathrm{R}^{2}=0.427$ \\
\hline
\end{tabular}

$r$ : correlation coefficient, $\mathrm{R}^{2}$ : coefficient of determination, correlation is a significant at $\mathrm{P}<0.05$ level.

Table 2 shows the correlation (r), P- value and coefficient of determination $\left(\mathrm{R}^{2}\right)$ between some electrolytic concentration sodium $\left(\mathrm{Na}^{+}\right)$, potassium $\left(\mathrm{K}^{+}\right)$and chloride $\left(\mathrm{Cl}^{-}\right)$in $\mathrm{s}$ sheep spleen. Results show the correlation between $\mathrm{Na}^{+}$and $\mathrm{K}^{+}, \mathrm{Na}^{+}$and $\mathrm{Cl}^{-}$and between $\mathrm{K}^{+}$and $\mathrm{Cl}^{-}$ were $(r=0.932, p=<0.0001, r=0.792, P=<0.0001$ and $r=$ $0.809, \mathrm{P}=<0.0001)$ respectively. The correlation coefficient (r) between (width and $\mathrm{Cl}^{-}$is a high correlation. Coefficient of determination $\left(\mathrm{R}^{2}\right)$ between $\mathrm{Na}^{+}$and $\mathrm{K}^{+}, \mathrm{Na}^{+}$and $\mathrm{Cl}^{-}$and between $\mathrm{K}^{+}$and $\mathrm{Cl}^{-}\left(\mathrm{R}^{2}=0.869, \mathrm{R}^{2}=0.628\right.$ and $\left.\mathrm{R}^{2}=0.654\right)$ respectively. A proportionate decrease in $\mathrm{Cl}$ relative to $\mathrm{Na}$ is characteristically seen in diarrhea, blood loss, and sweat (Smith 2009). Decreasing $\mathrm{Cl}$ without decreasing the proportion of $\mathrm{Na}$ can be followed by metabolic alkalosis such as abomasal torsion and vagus indigestion (5). Chiy and Phillips (28) suggesting $\mathrm{Na}: \mathrm{K}$ ratios $>10$ indicate $\mathrm{Na}$ sufficiency while less than 2.3 indicated $\mathrm{Na}$ deficiency.

Table 2: The correlation between electrolytic concentration $\left(\mathrm{Na}^{+}, \mathrm{K}^{+}\right.$and $\left.\mathrm{Cl}^{-}\right)$in spleen sheep

\begin{tabular}{ccc}
\hline $\begin{array}{c}\text { Electrolytes } \\
\text { Concentration }\end{array}$ & $\begin{array}{c}\text { Potassium }\left(\mathrm{K}^{+}\right) \\
(\mathrm{mmol} / \mathrm{L})\end{array}$ & $\begin{array}{c}\text { Chloride }\left(\mathrm{Cl}^{-}\right) \\
(\mathrm{mmol} / \mathrm{L})\end{array}$ \\
\hline Sodium $\left(\mathrm{Na}^{+}\right)$ & $r=0.932$ & $r=0.792$ \\
$(\mathrm{mmol} / \mathrm{L})$ & $\mathrm{P}=<0.0001$ & $\mathrm{P}=<0.0001$ \\
& $\mathrm{R}^{2}=0.869$ & $\mathrm{R}^{2}=0.628$ \\
Potassium $\left(\mathrm{K}^{+}\right)$ & & $r=0.809$ \\
$(\mathrm{mmol} / \mathrm{L})$ & & $\mathrm{P}=<0.0001$ \\
& & $\mathrm{R}^{2}=0.654$ \\
\hline
\end{tabular}

$r$ : correlation coefficient, $\mathrm{R}^{2}$ : coefficient of determination, correlation is a significant at $\mathrm{P}<0.05$ level.

Table 3 shows the Correlation (r), P- value and Coefficient of determination $\left(\mathrm{R}^{2}\right)$ between some biometrical parameters weight $(\mathrm{gm})$, length $(\mathrm{cm})$ and width $(\mathrm{cm})$ with some electrolytic concentration sodium $\left(\mathrm{Na}^{+}\right)$, potassium $\left(\mathrm{K}^{+}\right)$and chloride $\left(\mathrm{Cl}^{-}\right)$in sheep spleen. Results show a negative correlation between weight and $\mathrm{Na}^{+}$and between weight and $\mathrm{K}^{+}(\mathrm{r}=-0.161, \mathrm{P}=0.509$ and $\mathrm{r}=-0.214, \mathrm{P}=0.379)$ respectively, but the positive correlation between weight 
and $\mathrm{Cl}^{-}(\mathrm{r}=0.022, \mathrm{P}=0.929)$, length and $\mathrm{Na}^{+}(\mathrm{r}=0.147, \mathrm{P}=$ 0.549), length and $\mathrm{K}^{+}(\mathrm{r}=0.140, \mathrm{P}=0.567)$, length and $\mathrm{Cl}^{-}$ $(\mathrm{r}=0.267, \quad \mathrm{P}=0.270)$, width and $\mathrm{Na}^{+} \quad(\mathrm{r}=0.201, \quad \mathrm{P}=$ $0.410)$, width and $\mathrm{K}^{+}(\mathrm{r}=0.297, \mathrm{P}=0.216)$ and the correlation coefficient between width and $\mathrm{Cl}^{-}(\mathrm{r}=0.421, \mathrm{P}=0.072)$ is a high correlation. The coefficient of determination $\left(\mathrm{R}^{2}\right)$ between weight and $\mathrm{Na}^{+}\left(\mathrm{R}^{2}=0.026\right)$, weight and $\mathrm{K}^{+}\left(\mathrm{R}^{2}\right.$ $=0.046)$, weight and $\mathrm{Cl}^{-}\left(\mathrm{R}^{2}=000\right)$, length and $\mathrm{Na}^{+}\left(\mathrm{R}^{2}\right.$ $=0.022)$, length and $\mathrm{K}^{+}\left(\mathrm{R}^{2}=0.020\right)$, length and $\mathrm{Cl}^{-}\left(\mathrm{R}^{2}\right.$ $=0.071)$, width and $\mathrm{Na}^{+}\left(\mathrm{R}^{2}=0.040\right)$, width and $\mathrm{K}^{+}\left(\mathrm{R}^{2}=\right.$ $0.088)$ and between width and $\mathrm{Cl}^{-}\left(\mathrm{R}^{2}=0.177\right)$.Electrolyte imbalances commonly occur because of loss of electrolytes, shift of certain electrolytes, or relative changes in concentrations due to loss of water (4).

In conclusion the present study show the positive correlation between some parameters (weight, length and width) and some electrolytes concentration $\left(\mathrm{Na}^{+}, \mathrm{K}^{+}\right.$and $\left.\mathrm{Cl}\right)$ and a high correlation between (width and $\mathrm{Cl}-$ ), but the negative correlation between (weight and $\mathrm{Na}^{+}$) and between (weight and $\mathrm{K}^{+}$) in sheep spleen.

Table 3: The correlation between spleen parameters (weight, length and width) and electrolytes concentration $\left(\mathrm{Na}^{+}, \mathrm{K}^{+}\right.$and $\left.\mathrm{Cl}^{-}\right)$in spleen sheep

\begin{tabular}{lccc}
\hline \multirow{2}{*}{$\begin{array}{l}\text { Spleen } \\
\text { Parameters }\end{array}$} & $\begin{array}{c}\text { Sodium } \\
\left(\mathrm{Na}^{+}\right) \\
\mathrm{Mmol} / \mathrm{L}\end{array}$ & $\begin{array}{c}\text { Potassium } \\
\left(\mathrm{K}^{+}\right) \\
\mathrm{Mmol} / \mathrm{L}\end{array}$ & $\begin{array}{c}\text { Chloride } \\
\left(\mathrm{Cl}{ }^{-}\right) \\
\mathrm{Mmol} / \mathrm{L}\end{array}$ \\
\hline Weight & $r=-0.161$ & $r=-0.214$ & $r=0.022$ \\
(gm) & $\mathrm{P}=0.509$ & $\mathrm{P}=0.379$ & $\mathrm{P}=0.929$ \\
& $\mathrm{R}^{2}=0.026$ & $\mathrm{R}^{2}=0.046$ & $\mathrm{R}^{2}=0.000$ \\
Length & $r=0.147$ & $r=0.140$ & $r=0.267$ \\
(cm) & $\mathrm{P}=0.549$ & $\mathrm{P}=0.567$ & $\mathrm{P}=0.270$ \\
& $\mathrm{R}^{2}=0.022$ & $\mathrm{R}^{2}=0.020$ & $\mathrm{R}^{2}=0.071$ \\
Width & $r=0.201$ & $r=0.297$ & $r=0.421$ \\
(cm) & $\mathrm{P}^{2}=0.410$ & $\mathrm{P}^{2}=0.216$ & $\mathrm{P}^{2}=0.072$ \\
& $\mathrm{R}^{2}=0.040$ & $\mathrm{R}^{2}=0.088$ & $\mathrm{R}^{2}=0.177$ \\
\hline
\end{tabular}

$r$ : correlation coefficient, $\mathrm{R}^{2}$ : coefficient of determination, correlation is a significant at $\mathrm{P}<0.05$ level.

\section{References}

1. Samuelson DA. Textbook of veterinary histology. Missouri: Saunders Elsevier; 2007. 261-268 p.

2. Holcomb, GB. Small-scale agricultural alternatives: dairy and meat goats. USDA Cooperative State Research Service, The Office for Small-Scale Agriculture, Washington DC, USA. 1994.

3. Meyer AM, Vraspir RA, Ellison MJ, Cammack KM. The relationship of residual feed intake and visceral organ size in growing lambs fed a concentrate - or forage-based diet. Livest Sci. 2015;176:85-90.

4. Radostits OM, Gay ML, Blood DC, Hinchcliff KW. Veterinary medicine. $10^{\text {th }}$ ed. London: Baillier Tindall; 2007. 303-311 p.

5. Smith BP. Large animal internal medicine. $4^{\text {th }}$ ed. Maryland: Mosby; 2009. 636.0896L322, 1821p.
6. Kaneko JJ, Harvey JW, Bruss ML. Clinical biochemistry of domestic animals. $6^{\text {th }}$ ed. London: Academic; 2008. 117-138 p.

7. National Research Council. Nutrient requirements of dairy cows, $7^{\text {th }}$. Edition. Washington DC. National Academy Press. 1989.

8. Salt Institute. History of salt. [http://www.saltinstitute.org/38.html] 2007-12-11.

9. Mongin P. Recent advances in dietary anion - cation balance: application in poultry. Procee Nutrit Soc.1981;40(3):285-294.

10. Leeson S, Summers JD. Scott's Nutrition of the Chicken. Guelph: University Books; 2001. Nottingham University Press ; 4th edition.

11. Silva AVF, Freier WJ, Satto J. Estudo de diferents indicadores do estresse caloric em de corte. Revista do setor de Ciěncias Agrarias. 1993;12:88-90

12. Schröder B, Diener M. Grundlagen der Zellphysiologie. In: Engelhard W, Breves G. Physiologie der Haustiere. $2^{\text {nd }}$ ed. Stuttgart: Enke Verlag; 2005. 5-21.

13. Youn $\mathrm{JH}$, McDonough AA. Recent advances in understanding integrative control of potassium homeostasis. Annu Rev Physiol. 2009;71:381-401.

14. Cheng CJ, Kuo E, Huang CL. Extracellular potassium homeostasis. Insights from hypokalemic periodic paralysis; Seminars Nephrology. 2013 May; 33(3): 237-247.

15. Brouns, F. Rationale for upper limits of electrolyte replacement during exercise. Internat J Spotrs Nutrit. 1992;2:229-38.

16. Mounib MS, Evans JV. The potassium and sodium contents of sheep tissues in relation to the potassium content of erythrocytes and the age of the animals. Biochemal J. 1960;75:77-82.

17. Hosey RG, Mattacola CG, KrissV, Armsey T, Quarles JD, Jagger J. Ultrasound assess ment of spleen size in collegiate athletes. $\mathrm{Br} \mathrm{J}$ Sports Med. 2006;40:251-4.

18. Kutlu R, Yakinci C, Durmaz Y, Baysal T, Ozgen U. Sonographic evaluation of liver and spleen sizes in School-aged children. Turk J Med Sci. 2000;30:187-19.

19. Konuş OL, Ozdemir A, Akkaya A, Erbaş G, Celik H, Işik S. Normal liver, spleen, and kidney dimensions in neonates, infants, and children: Evaluation with sonography. AJR Am J Roentgenol. 1998;171:1693-8

20. Dittrich M, Milde S, Dinkel E, Baumann W, Weitzel D. Sonographic biometry of liver and spleen size in childhood. Pediatr Radiol. 1983;13:206-11.

21. Henderson JM, Heymsfield SB, Horowitz J, Kutner MH. Measurement of liver and spleen volume by computed tomography. assessment of reproducibility and changes found following a selective distal splenorenal shunt. Radiol. 1981;141:525-7.

22. Al-Imam O, Suleiman A, Khuleifat S. Ultrasound assessment of normal splenic length and spleen-to-kidney ratio in children. East Mediterr Health J. 2000;6:514-6.

23. Niederau C, Sonnenberg A, Muller JE, Erckenbrecht JF, Scholten T, Fritsch WP. Sonographic measurements of the normal liver, spleen, pancreas and portal vein. Radiol. 1983;149(2):537-40.

24. Khalel E M . Anatomical and histological study of the spleen in iraqi sheep (Awasi sheep). Bas.J.Vet.Res. $2010 ; 10(.2)$ : 163-171.

25. Piccione G, Messina V, Vazzana I, Dara S, Giannetto C, Assenza A. Seasonal variations of some serum electrolyte concentrations in sheep and goats. Comp. Clin. Pathol. 2011; 21 .10.1007/ s00580-011-11983 .

26. Piccione G, Casella S, Giannetto C, Fazio F, Caola G. Effects of short time fed deprivation on some blood electrolytes in horses. Folia Vet. 2007:51:137-141.

27. Blaustein MP. Sodium ion, calcium ion, blood pressure regulation and hypertension: a reassessment and a hypothesis. Am J Physiol. 1977;232(3):65-73.

28. Chiy, C P, Phillips, C J C. Sodium in ruminant nutrition, production, reproduction and health.1995; pp. 107-114. In: Sodium in Agriculture. Eds. Phillips, C.J.C.; Chiy, P.C. Chalcombe Publications, Canterbury. 